\title{
Religious policies of Anna Ivanovna
}

\author{
Adam Drozdek \\ Duquesne University in Pittsburgh \\ Pittsburgh, USA \\ drozdek@duq.edu
}

A. Drozdek, Polityka religijna Anny Iwanowny, Elpis, 20 2018: 17-24.

\begin{abstract}
Anna Ivanovna was an empress of Russia in 1730-1740. The process of dismantling the authority of the church that started under Peter in 1700 was continued during Anna's reign. The clergy were treated as civil servants serving the interest of the state through their spiritual service, as governmental clerks whose highest obligation was to the empress. The ecclesiastical life was disrupted, its spiritual role diminished, and the clergy was whipped to submission by harsh means. Orthodoxy was a mandatory religion. Conversion to other faiths was punishable. Peter's discriminatory policies against Old Believers were continued. Anna herself was devoted to entertainment and everything else took the second place including her involvement in the affairs of the state as well as her personal spiritual life.
\end{abstract}

\begin{abstract}
Streszczenie: Anna Iwanowna była carycą w latach 1730-1740. Proces demontażu autorytetu kościoła, który rozpoczął się za Piotra I w 1700 r. był kontynuowany podczas panowania Anny. Duchowni byli traktowani jako urzędnicy służący interesowi państwa poprzez ich duchową służbę, ako urzędnicy rządowi, których najwyższym obowiązkiem była służba carycy. Życie kościelne zostało zakłócone, jego rola duchowa uległa zmniejszeniu, a duchowieństwo było karane surowymi środkami. Prawosławie była obowiązkową religią. Nawrócenie się na inne wyznania było karalne. Kontynuowana była polityka dyskryminacyjna Piotra I wobec starowierców. Anna poświęcała się głównie rozrywce i zabawom, a wszystko inne zeszło na dalszy plan w tym jej zaangażowanie w sprawy państwa, a także jej osobiste życie duchowe.
\end{abstract}

Keywords: Anna Ivanovna, Orthodoxy, Old Believers

Słowa kluczowe: Anna Iwanowna, prawosławie, starowiercy

Anna Ivanovna/Ioannovna, born in 1693, daughter of Peter I's brother Ivan, was married off in 1710 by Peter to the duke of Courland, Frederick William. However, Frederick died a few weeks after the wedding ceremony and Anna was sent in 1711 to Courland where she spent 19 years in Mitau (today Jelgava in Latvia) with only occasional visits to Russia. After very brief rules of Peter's peasant lover and then wife named Catherine I and, after her, a young teenager Peter II, Anna was elected as a new monarch and she was an empress for a full decade, 17301740.

At the beginning Anna refuted any attempts to undermine the scope of her imperial authority by reasserting herself as "Her Imperial Majesty, the All-Russian Autocrat" (PSZ 8.5501) ${ }^{1}$ requiring an oath from all subjects: I swear

\footnotetext{
The following references will be used:

D - Petr V. Dolgorukov, Mémoires du Prince Pierre Dolgoroukow, Genève: Cherbuliez 1867, vol. 1.

$\mathrm{K}$ - А. Кудрявцев (ed.), Книга записная имянным письмам и указам Императриц Анны Иоанновны и Елисаветы Петровны Семену Андревичу Салтыкову. 1732-1742 гг., Чтения в Императорском обществе истории и древностей российских при московском университете 1878, bk. 1, pp. 1-236.

$\mathrm{PSP}$ - Полное собрание постановлений и распоряжений по ведомству Православнаго Исповедания Российской империи, Санкт-Петербург: Синодальная. типография 1869-1915.

PSZ - Полное собрание законов Российской Империи, Санктпетербург: Печатано в Типографии II Отделения Собственной Его Императорскаго Величества Канцелярии 1830.

Т - Б[орис] В. Титлинов, Правительство императриць Анны Иоан-
}

to be "the loyal, good and obedient slave ( $\mathrm{rab}$ ) and subject" even to scarify my life if need be (8.5509). She vowed to continue his uncle's policies - whose name would constantly appear in her ukases - including church policies: we want, she stated, to protect the laws of the Eastern church, so the Synod should see to it that the subjects "observe God's laws and Holy mysteries/sacraments and other traditions established by the holy church" and come to church every Sunday. Abandoned churches should be restored, schools should be established as required by the Spiritual regulation, missionary work should be extended to convert to Orthodoxy non-Christians and schismatics (8.5518).

\section{The Orthodox church}

Following old tradition, Anna proclaimed that her authority "is the gift given to Us by the Only King of Kings, Our God who gives and supports Tsarist scepters" (PSZ 8.5517). The divine provenance of the tsarist rule had been and would be emphasized by all Russian monarchs, but this should not be a one-time statement. People should pray for Her Imperial Majesty in church (8.5500), obviously, upon her coronation $(8.5517,8.5536)$, and people should pray in churches for Anna and her imperial family (8.5518). In

новны в его отношениях к делам православной церкви, Вильна: Типография "Русский почин” 1905. 
all church services the empress and her family should be elevated (8.5670, 9.6718, PSP 7.2283). This was not an innocuous request. Bishop Lev Iurlov of Voronezh celebrated a church service during which he mentioned the name of the grand duchess Evdokia, mother of prince Alexei, but not Anna's, since apparently in his mind the fact of her ascendance to the throne was not quite firmly settled. After an investigation, he was defrocked and exiled to Krestnyi monastery where he would be isolated from others ( $\mathrm{T}$ 90$91,102)$. Something that could have been explained as an act of an honest mistake or forgetfulness was viewed - by Anna and the Secret Chancellery - as an act of mutiny and treason, an expression of political opposition against the new autocrat, and that resulted in thousands upon thousands of investigations followed by flogging, defrocking, exile to Siberia, and hard labor. Woe to those who did not pray for the empress and did not express a gratitude for her divine appointment. Denunciation of such perceived ingratitude became for many a tool of settling local scores with those against whom a grudge was held. The perceived infractions against the authority of Anna often reached the level of pettiness. Varlaam, archbishop of Pskov, was sent to Sviatogorskii monastery in 1735 (T 155) for calling her in one of his letters her highness instead of her imperial highness (PSP 8.2843) and for not mentioning her name for the second time in the church service (T 157).

An oath was required of all the clergy (PSP 7.2298; 7.2518). It turned out that some 5,000 priests did not make it (9.7070). Sometimes this was caused by sickness, young age, by taking an oath but not signing it, even by drunkenness (T 204). The government considered it to be a political act and punished it with flogging and by investigation by the Secret Chancellery (205).

Holding particular religious views was not quite a personal choice, at least, not without consequences. Anna's law required that all people beginning with 7-year old children would go to confession during Lent and take communion or do it during two following Lents if there were extenuating circumstances; otherwise, the person was to be fined. During confession, people were to show how they crossed themselves - using the 2-finger or 3-finger sign and those who refused to use the 3-finger sign should be reported. Priests were to take confession only from their own parishioners (PSZ 10.7226; 11.8204). Petrine punishments (5.3169) followed for violating the law.

The crime of not taking an oath upon Anna's ascendance to the throne was used to replenish the army. As needs of the army grew with the prolongation of the war with Turkey, drafting became more and more exacting: in 1726 one recruit was drafted out of 200 souls, in 1727 one out of 305 , in 1729 one out of 324 , in 1730 one out of 320 , in 1732 one out of 288.5 , in 1733 one out of 102 , in 1734 one out of 169 , in 1736 one out of 125 , in 1737 one out of 98 , in 1738 one out of 120 souls, and in 1739 one out of 120 (PSZ 10.7872). Those from among the clergy and church staff and their children from bishop and monastic houses who did not take an oath were to be flogged and those who were fit for military service were to be drafted as an example for others; drafting also affected those from among church staff who were considered unemployed. ${ }^{2}$ From 1737, children of clergy and church staff could avoid being drafted if they found a replacement or paid 200 rubles, a prohibitive amount for most; then they were to go to school afterwards for 3 years to learn grammar, rhetoric, philosophy (only if they wanted), arithmetic, and geometry; those who were lazy were to be drafted; those who didn't want to become priests after school, were to become merchants or tradesmen and pay taxes (10.7169 10.7364; 10.7385; 10.7389; cf. 12.9113).

The army also needed horses, and so it was decided that cavalry horses should be taken without compensation from all people, secular and ecclesiastic (PSZ 9.6494): in 1733, one horse for every 370 souls from all estates, including churches. Churches and other institutions supported by the state were to give one horse for every 370 rubles of support; if they got less than that, two or more institutions were to join forces (9.6497); the number was 253 in 1736 (9.7048), 284 in 1737 and one fourth of horses from "horse factories" (stud farms) (10.7430), 200 in 1738 (10.7611). Thankfully, since 1737 , horses were not to be taken from priests and small monasteries where there were only working horses (10.7205).

At least, on paper, Anna expressed her interest in the affairs of the church. "We have always particular concern, most of all, for holy churches had educated clergy for better affirmation of the Christian law and piety with teaching and preaching of the word of God from Sacred Scriptures, since the simple and base (подлый) people by not having in their heart the fear of God and proper inclination to good works, out of ignorance and coarseness fall into all evil," which leads to their perdition. Bishops were to establish seminaries "since learning is very useful and needed for the State, first, for the education of the human reason/mind and most of all for perfect knowledge and true honor of the Almighty Creator and the Maker of all, God, and for affirmation of Our Christian Law, for the inclination to espouse divine commandments and for correct Christian life and for salvation." From knowledge "are born and flower all virtues" and knowledge is needed for missionary work among non-Orthodox nations in Russia (10.7660). Such grand proclamations remained largely vacuous.

From 1734, only widowed priests and deacons and soldiers after service could become monks, but permission was needed for it. ${ }^{3}$ Bishops who violated this restriction would pay 500 rubles, monastery authorities would be defrocked, their property would be confiscated, and they would be sent to labor for life (PSZ 9.6585). There were not many retired soldiers and widowed priests willing to become monks. Also, considering the fact that many monks suffered punishments for perceived crimes, many cloisters became depopulated. When in 1735 bishop Aaron sent a memo bringing this problem to Anna's attention,

PSZ 9.7070; 9.7133; 9.7138; 10.7158; 10.7164; 10.7198, 10.7490; 10.7738; 10.7764; some exceptions applied: $10.7144 ; 10.7311 ; 10.7790$.

3 After Anna's death, restrictions on who can become a monk/nun were significantly eased up (11.8303). 
she requested an investigation of this insolent bishop who violated the law (8.5546) that prohibited sending requests directly to her (T 313).

Moreover, as the result of regular draft and of the draft as a punishment of not taking the oath, churches became severally understaffed or lost their staff altogether and yet the cure was to school children under 15, which, even if followed, would take years to do and besides, it was impossible to do since there were no or very few competent teachers and instructors in schools to prepare pupils for priesthood. It was ordered, following the Spiritual Regulation, that in all eparchies schools were to be established; however, they were to be funded by churches and monasteries (PSZ 10.7364), by money that they did not have. As the result, schools were opened and quickly closed because of lack of teachers and funds ( $\mathrm{T} 416)$. The reality forced the government to considerably lower standards for priesthood. In 1739 it was allowed that priests newly elected by parishioners were to be first instructed for at least 3 months under leadership of the bishop in God's commandments, church traditions, priestly duties, interpreting the Scriptures with exams every week, and in conducting an exemplary way of life; there were to be one or two priestly instructors in each eparchy. When the bishop found the choice for the priest unsuited, he was not to become a priest (PSZ 10.7734; 10.7749). Also, priests who did not take the oath at the beginning of Anna's reign were allowed to remain priests if there was no other option, but they had to pay a fine (10.7790). The problem was particularly acute in Siberia to the extent that in the Irkutsk eparchy, a lay people were allowed to become priests (usually sons of priest became priest after death of fathers) if parishioners agreed to pay their tax from which they would be freed as priests (10.7836). Priests who falsified the document saying that they took the oath and paid a fine could resume their priestly duties (11.8040). Finally, fine and flogging would be forgone for those who did not take the oath because of their simplemindedness (простота), and they could exercise their church duties after taking the oath (11.8130). In other words, those who did not take the oath "not out of malice or stubbornness or not out of any other evil reason" should be forgiven (11.8148).

Cloisters were viewed with suspicion by Peter I, and this did not change under Anna and the government also regulated monastic life. Vagrant monks were not to be let into monasteries, some of them pretenders, but reported for investigation. The ostensible concern was that some become monks to have an easy life and some defiled the image of monks. Therefore, the following rules were enacted: §1. Keep detailed registers of all people in monasteries. §6. Send wanted notices to capture monks who escaped. §8. Don’t allow any monk to leave the monastery just for asking nor expel them as a punishment. §9. The bishop could transfer monks from one monastery to another only for some important reasons. §11. Monks who were allowed to go outside the monastery were to have a passport. §12. Report monks who come to the monastery without a passport. §13. A monk was to report to the abbot on another monk "when he sees something wrong." When the abbot did nothing, to the bishop, when he did nothing, to the Synod. $§ 15$ All these rules applied also to convents (PSZ 8.6177; PSP 7.2604; PSZ 9.6362; 9.6561). Detailed questionnaire was provided to question monks who came to monasteries without passports (9.6511). However, priests and church staff were not to admit monks into their homes even if they had passports (9.6561).

Cloisters were to serve the government and not be limited to purely religious life. Already under Peter, retired soldiers were sent to monasteries (PSZ 5.3409, 6.3576, 7.4151). Abbots bitterly complained about it since soldiers did not help in anything and were disobedient, beat and cursed monks, violently extorted food and so people were afraid of becoming monks; there were even cases of soldiers killing monks ( $\mathrm{T}$ 320). Moreover, the mentally ill prisoners were sent to cloisters for care and the Secret Chancellery was to be informed if they recovered (9.6803; 10.7793). Widows of military officers were to be placed in convents for care (10.7761). By sending violators of, for example, the law requiring taking the oath to cloisters, they effectively served as prisons for political prisoners (T 321) and monasteries were responsible for watching them (322).

Intervention of the government concerned even the minutia of church rituals. Building uniform altars in churches was prescribed by specifying sizes: 1 arshine 6 vershoks high, 1 arshine 8 vershoks long, 1 arshine 4 vershoks broad (about $1 \times 1.07 \times .9 \mathrm{~m})($ PSZ 9.6624). Graves were to be at least 3 arshines $(2.1 \mathrm{~m})$ deep and dirt was to be firmly pressed after burial to prevent smell to come out (10.7616). It was also prescribed that candles should be twice as fat at the bottom as at the top, and the top part was to be one fourth of the bottom (9.6994).

The process of dismantling the authority of the church that started under Peter in 1700 by not appointing a new patriarch that culminated under his rule with the Spiritual Regulation and the establishment of the Synod was wholeheartedly continued under Anna's rule. The clergy were treated as civil servants serving the interest of the state through their spiritual service, as governmental clerks whose highest obligation was to the empress. The ecclesiastical life was disrupted, its spiritual role diminished, and the clergy was whipped to submission by harsh means. ${ }^{4}$

\section{Non-Orthodox faiths}

There was a measure of toleration of other faiths: a 1735 ukase stipulated that all Christians could freely exercise their faith by having church services; however, no foreign priests could convert anyone to their faith (PSZ 9.6693).

Traditional hostility against Catholicism manifested itself right from the beginning of Anna's reign. One

\footnotetext{
4 As the outcome of Anna's policies, "the dignity of the ecclesiastical authorities was lowered, the higher hierarchy was scared, the clergy and monks/nuns were terrorized, religious and church life did no go its normal course" (T 465)
} 
1730 ukase stated that Bernardine Werbicki, who came from Poland to convert people to Catholicism, was to be turned back to Poland with the request that such people should not be allowed to come to Russia since they would be punished if they did (PSZ 8.5538). Some noblemen in Smolensk who converted to Catholicism were sent to Siberia then to Moscow where they publicly converted back to Orthodoxy; it was ordered that they should be watched closely and arrested if they again relinquished Orthodoxy; they signed a declaration in which they declared that they would be sentenced to death if they slipped back to "the Roman faith" (PSP 7.2408). For accepting Catholicism, Alexei Apraksin was made a court jester and so was his father-in-law, Mikhail Golitsyn (T 451).

Jews, by the law, were to be expelled from Russia, which was enacted by Catherine I (PSZ 7.5063) and rather tepidly confirmed by Anna (11.8169), but they were tolerated to some extent - after all, one of the court jesters was "a baptized Portuguese Israelite" and they were allowed to come to Russia to bring their goods to the market (as allowed under Peter II, PSP 8.5324, §14, and then by Anna, PSP $8.5852 ; 11.8169$ ) - but woe to those who abandoned Orthodoxy for Judaism. After the wife of captain Alexandr Voznitsyn denounced for abandoning Orthodoxy for the Jewish faith at the instigation of a Jew, merchant Leibov, it was declared that "for blaspheming against Christ our Savior and for rejection of true Christian law and for accepting Jewish faith" Voznitsyn should be burned at the stake "so that others seeing it would not step away from the Christian law"; Leibov should meet the same end (10.7612).

Becoming a Muslim was also punishable. In 1740, Cossack Roman Isaev was sentenced to death for accepting Islam (PSZ 11.8125). However, the government was quite supportive in the missionary work among Muslims funding the same year four schools and even a special Office for the Newly Baptized (Новокрещенская Контора) was created to address the issue $(11.8236,8239)$.

Pagan practices were addressed with harsh measures. Wizards were to be punished by being burned at the stake, unless they renounced their practices, and those who used their services were to be flogged with the knout. It was prohibited even to talk to them (PSZ 8.5761; 9.6748). To fight unorthodoxy, in each town there was to be a priest watching for the appearance of superstition, which included ecstatic behavior: hysterics (кликуши) would be sent to secular court (10.7450). Anna even sent an indignant letter to Saltykov stating that such hysterics showed up in Moscow and the bishop and Saltykov had done nothing about it instead of arresting them (K 193-194). Incidentally, the reliance on supernatural intervention in natural phenomena was not renounced altogether. A 1735 ukase required that special church services should be held during drought, bad weather, and a plague; however, people should not pray about the weather when it was good but

\footnotetext{
5 Jan d'Acosta/Lacosta/Jean da Costa whom Anna inherited from Peter (D 135, 380).
}

only when drought, etc. were caused "through the righteous wrath of God because of multiplication of human sins" (9.6603).

\section{Old Believers}

Schismatics were not considered as a different denomination and thus they did not have the same rights as non-Orthodox faiths (T 418). Holding on to the Old Belief was considered "a temporary illness" and giving Old Believers the same rights as other faiths would solidify the schism (419).

There is a view that Anna had a soft spot for Old Believers and even defended them against decisions of the Synod $^{6}$; however, her policies concerning Old Believers were anything but friendly toward them. From the very outset a stern ukase was issued stating that if someone converted an Orthodox believer to Old Belief, he should be sentenced to hard labor for life and his possessions should be confiscated (PSZ 8.5554). Harsher yet, the Synod should make any effort to uproot the false teachings of schismatics. If someone caused any problems in this effort, "they will be sentenced to death without mercy as enemies of the holy church" (8.5564).

The family life of Old Believers was not free from governmental intervention. Children of registered schismatics were to be baptized to Orthodoxy and they were not to be taught by their parents "the schismatic heresy," and Old Believers must not even try to convert anyone to the schismatic faith (PSZ 8.6149; 11.8083). Old Believers who caught someone into their "deadly net of charms/ heresies" would be sent for life to the galleys and their property would be confiscated. Children baptized in Orthodoxy must not be taught the schismatic faith and should be presented in the church at the age of 7 for confession and communion (9.6928). The intention apparently was that the Old Belief would gradually disappear with the death of the living Old Believers. ${ }^{6}$

In 1716, Peter instituted a double tax for Old Believers (PSZ 5.2991) and this taxing remained in place during Anna's reign. In addition, fees were to be paid by Old Believers, different fees for different classes; a half of the fees paid by men should be paid by women (PSZ 8.6149; 11.8083).

As encouragement for conversion to Orthodoxy, a ukase reiterated Peter I's inducement of release for three years from taxes for the Old Believers who converted (PSZ $8.5737,9.6518)$. Converted Old Believers were to be freed from paying double tax "so that other seeing that would also convert." The balance of their debt concerning the tax from before conversion would be forgiven (9.6442; 8.5998).

The fear of conversion from Orthodoxy still existed. As a measure to prevent that from happening, passports were not to be issued to schismatics who lived in hermit-

\footnotetext{
Смирнов, op. cit., p. 120.
} 
ages in Nizhnyi Novgorod gubernia since with these passports "they will seduce the Orthodox [believers in other gubernias] and turn [them] from Christian faith to their schismatic superstition" (PSZ 8.6134).

Curiously, the measures undertaken against Old Believers backfired. They paid double tax, but as considered to be untrustworthy, they were relieved from other duties, in particular, from military service, and thus people escaped to their places for this very reason. To plug this loophole, a 1738 ukase required to draft one recruit from every 50 schismatics and take one horse from 160 souls [100 in the text] (PSZ 10.7702; 10.7762).

\section{Biron, Ostermann, Prokopovich}

Were the policies of Anna's times Anna's policies? There is a widely accepted conviction that Anna surrounded herself with foreigners who, basically, took over the governmental decisions. One of them was Ernst Biron and even the term Bironovshchina was coined to indicate that governmental strings were primarily in Biron's hands. Biron, it is said, made sure that popular dissatisfaction and rebellions did not reach Anna "who spent her life on the couch in nightgown with her favorite or playing cards." "The ultimate power over her held relentlessly until the end the Duke of Courland and to please him, the mightiest monarch in Christian lands relinquished her freedom [to him] so that not only her actions fitted his ideas up to the slightest details, but even one moment could not pass by without him; and very seldom she received anyone else when he was not there."

Anna also created the Cabinet as a buffer between her on one side and the Senate, the Synod, and other governmental agencies on the other. The Cabinet consisted of three members, chancellor Gavriil Golovkin, vice-chancellor Andrei Ostermann, and counselor Alexei Cherkasskii (a 1731 ukase, PSZ 8.5871, although references to the Cabinet were made in previous ukases, 8.5827, 8.5869), and it was dominated by Ostermann, ${ }^{9}$ a shrewd politician, who had already made his mark under Peter and who was considered the driving force behind governmental policies. Another power player was considered to be Theofan/ Feofan Prokopovich who had a personal stake in church policies as the author of the Spiritual Regulation and someone embroiled with other ecclesiastics in squabbles which concerned as much theological issues as personal ambitions. Under Anna, Prokopovich had decidedly the upper hand over his opponents and exercised his power

\footnotetext{
Н. Ю. Веретьев, Анна Иоанновна, ее личность, интимная жизнь и правление, Berlin: Heinrich Caspari Verlagebuchhandlung 1912, p. 49.

Ernst von Münnich, Die Memoiren, Stuttgart: Verlag der I.G. Cotta'schen Buchhandlung 1896, p. 171.

9 Cherkasskii was called by his contemporaries the body of the Cabinet, Ostermann - its soul, B[асилий Н.] Строев, Бироновщина и Кабинет министров. Очерк внутренней политики Императрицы Анны, vol. 1, Москва: Типография Императорскаго Московскаго Университета 1909, p. 27; Евгений А. Anisimov, Анна Иоанновна, Москва: Молодая гвардия 2002, р. 166.
}

quite mercilessly. He presented his opponents, supporters of already deceased Iavorskii and his recently published Rock of Faith ${ }^{10}$ and severe critiques of Protestant coloring of Orthodoxy promoted by Prokopovich. as political opponents of foreign dignitaries surrounding Anna who were Protestants and thus as opponents of Anna and her rule. Consequently, many of these opponents were investigated and punished with defrocking and exile by the Secret Chancellery. Because of the influence Prokopovich exercised, it was proposed that, at least until his death, Anna's reign should be called Feofanovshchina. ${ }^{11}$ This is all true to considerable extent, since in all her life Anna indicated little interest and insight in domestic and foreign policies except when they touched her personally.

\section{Anna}

There is one volume of Anna's correspondence from Mitau. Her letters are mostly of postcard quality and length and are written in lamentable Russian: short greetings, wishes of merry Christmas, wishes of everything good on the occasion of a name day, and the like. Only occasionally she pleaded for money: to Catherine, Peter's wife, she wrote: "I have nothing ... I don't have promised diamonds, nor laces, nor linen, nor promised dress: allow me to do it, my little mother, according to your high grace, from the money sent here." To Peter she wrote: "With money that is left I really cannot support myself as to dresses, linen, laces and, if possible, diamonds, and silver, horses and other things in the new empty palace, not only according to my rank, but also according to the rank of former widowed Courland duchesses. Also, the wives of the local nobility have jewels and clothing [that is] not [too] shabby because of which I am in these lands not without estrangement."12 She could not support herself since she could not buy diamonds. That was likely one of reasons why Peter did not even answer.

Later in the century, Catherine II would hold the reins of the government very tightly in her hands. Anna had very little interest in the governing process. Poorly educated, she did not try to improve herself in extending her horizons and devoted herself almost exclusively to entertainment.

Anna raised pomp in the court to a new level: "magnificence ran into excess, and cost the court immense sums. It is incredible how much money went out of the empire upon this account. A courtier that did not lay out above two or three thousand rubles, or from four to six hundred

10 This voluminous book was published posthumously in 1729 and yet in 1732 Anna ordered the governor of Moscow, Saltykov, to collect all copies of the book from the printer and bookstores and send them to St. Petersburg not allowing anyone to print new copies without Anna's permission (K 45).

11 T iii, 32; K[azimierz] Waliszewski, L'héritage de Pierre le Grand, Paris: Librairie Plon 1900, p. 181.

12 Письма русских государей и других особ иарскаго семейства: [vol. 4:] Переписка герияогини Курляндской Анны Ивлновны, Москва: В типографии Сергея Орлова 1862, pp. 42, 89. 
pounds a year in his dress, made no great figure." ${ }^{\prime 3}$ She was sometimes praised for bringing culture to the court by spending lavishly on theater and opera, but her taste was rather unsophisticated: many comedies were played in court, but she preferred slap-stick comedies during which she laughed "with her harsh laughter with her mouth wide open" (D 379). One of the favorite amusements of the "savage empress" was to put five jesters with faces to the wall and the sixth should kick each one so that they fell on their backs to the floor. Another time, she ordered them to fight among themselves until blood flowed and Anna laughed very loudly (384). She loved hunting to the extent that guns were kept in many rooms in the palace and when the spirit carried her, she would shoot at birds from windows. ${ }^{14}$ She liked to watch others dance, which could be perilous to the dancers: once enraged Anna slapped on the face four women who, intimidated, messed up figures of the dance while dancing in front of her. ${ }^{15}$ She had six court jesters, three of them Russian noblemen degraded to this humiliating position for some infractions: Nikita Th. Volkonskii became a jester as an act of vengeance of Anna against his wife for her political meddling against Anna before Anna became empress. His duty was to take care of Anna's dog. Alexei P. Apraksin became a jester as a punishment for converting to Catholicism. Mikhail A. Golitsyn became a jester for the same religious infraction; he was called Kvasnik since his duty was to give Anna kvas; she drank half a glass and poured the rest on his head (D 380-383).

Sometimes her entertainment went beyond bizarre. After one of Anna's servants, Buzheninova, expressed her desire to marry, Anna decided that Golitsyn should be her bridegroom and for their wedding a "masquerade commission" was formed headed by Tatishchev. ${ }^{16}$ "In 1740, a strange wedding took place. Prince Golitsyn, who at that time was called Kvasnik, got married, for which wedding people from the entire country were gathered, of various ranks and languages, from the basest nations, namely the Votyaks, Mordvins, Cheremis, Tatars, Kalmyks, Samoyeds and their wives and other nations from the Ukraine and following the feet of Bacchus and Venus, in clothing like them and with shouting to make the wedding joyful. They passed the court. The bridegroom with his bride sat in a cage made for the occasion that was on an elephant and the rest of the wedding procession of the nations just mentioned followed on [sledges pulled by] harts, dogs, and pigs, playing music of their nationalities and playing their toys. Also, the sledges were strangely made in the likeness of animals and sea fish and some in the image of odd birds. The bridal chamber was in an ice

\footnotetext{
13 [Christopher Herman] Manstein, Memoirs of Russia, London: Printed for T. Becket and P.A. De Hondt 1770, p. 249

14 С.Н. Шубинской; Императрица Анна Иоанновна, придворный быт и забавы, 1730-1740, Русская Старина 7 (1873), no. 3, p. 339.

15 Ekaterina R. Dashkova, Memoirs of the Princess Daschkaw, London: Henry Colburn 1840, p. 105.

16 Шубинской, op. cit., p. 347. This wedding is considered to be "“the calling card' of Anna's reign," Игорь Курукин, Анна Иоанновна, Москва: Молодая гвардия 2014, р. 217.
}

house." ${ }^{17}$ Incidentally, Anna tried to match here equally bizarre ceremonies organized personally by her uncle Peter to mention only a wedding service for former tutor of Peter, Zubov. Anna tried to outdo Peter by providing the newlywed with a house built entirely from ice, including the bridal bed. Outlandish as it was, the ice house was also an engineering marvel, $17 \mathrm{~m}$ long, $5.3 \mathrm{~m}$ wide and $6.4 \mathrm{~m}$ high with various figures and working canons, also out of ice, accompanying it. ${ }^{18}$

No expense was spared for Anna's pleasures. The maintenance of her "horse school" (manège) cost 100,000 rubles a year. ${ }^{19}$ She repeatedly demanded from the governor of Moscow Saltykov that he buy for her sable and fox furs, as many as he could find; Saltykov recorded at one point that he paid 900 rubles for two fox furs and 950 rubles for three sable furs (K 140). It must be remembered that a member of the Academy of Science received between 600 and 800 rubles a year, ${ }^{20}$ and this was a very well-paid job. It is not that Anna did not know the concept of restricting expenses. She commanded Saltykov to tell the abbess of the Ascension convent that she should use money for indispensable things and should not squander it; she also asked that the abbess kept record of her expenses (K 61). It is the same monastery in which a month before Saltykov was ordered to give one ruble to each nun and some bread (50). Anna was apparently concerned that this one ruble could be squandered. It is quite possible that as a response to Anna's command, the abbess limited rations of bread given to nuns, about which they complained (157).

Her own advice about using money for indispensable things alone Anna did not apply to herself, unless what she purchased was considered indispensable. And so interminable requests were sent to Saltykov to buy expensive fabric and tapestry for curtains and wall covering, toys, porcelain, horses, peacocks, a talking starling; he was also supposed to ask various people - which meant confiscation - for paintings, diamonds, gold and silver items, and musical instruments.

As to her spiritual life, Anna did not reveal anything in that respect. In her letters, she frequently mentioned archimandrite Varlaam, her confessor, asking Golitsyn to accommodate him when he traveled for some ecclesiastical

\footnotetext{
7 Василий А. Нащокин, Записки, Русский архив 1883, no. 4, p. 288; Manstein, op. cit., p. 250-251. With this wedding, which was "a comicrough punishment [Anna] amused herself in the apostasy prohibited by the church" in view of F[riedrich] W. Barthold, Anna Joanowna. Cabinet, Hof, Sitte und gesellschaftliche Bildung in Moskau und St. Petersburg, Historisches Taschenbuch 7 (1836), p. 375.

18 It was described in some detail, with illustrations, by Georg Kraft, a member of the Academy of Sciences, Георг В. Крафт, Подлинное и обстоятельное описание построеннаго в Санктпетербурге в генваре месяче 1749 года Ледянаго дома и всех находившихся в нем домовых вещей и уборов: С приложенными при том гридорованными фигурами, Также и некоторыми примечаниями о бывщей в 1740 году во всей Эвропе жестокой стуже, [Санктпетербург]: Печатано при Императорской Академии наук 1741; abbreviated in Г[еорг] Ф. Крафт, Ледяной дом, Русская Старина 7 (1873), no. 3, pp. 354-360. An artistic rendering of the ice construction is given by Vasilii Jakobi in his painting Ice house (1878).

19 Шубинской, op. cit. p. 339.

20 Manstein, op. cit., p. 391.
} 
errands to Moscow and speaking about him with the endearing batiushka. She surely did not discuss any religious matters in her letters using only occasionally stock phrases such as, "God may protect you," "thank God," and the like. One contemporary said about her that she was God-fearing but a bit superstitious. ${ }^{21}$ She supported some churches, e.g., some money was given to restore a church after fire (PSZ 8.5834); occasionally ruled in favor of individual churches or cloisters concerning their property (e.g., 8.5574, 8.5686, $8.5887,9.6544,9.6891,10.7524)$, also she occasionally ruled in favor of the non-Orthodox as in the case of ordering to give back an evangelical church to citizens of Narva (9.6323). This was not much considering that in 1737 there were 16,000 churches in the country (10.7734). ${ }^{22}$ Sometimes she requested sending her some church paraphernalia. ${ }^{23}$ Considering her standard of religiosity expressed in her legislation: going to church service and to confession and communion once a year, this very likely was a limit of her religious life: following rituals and leaving church life behind in her everyday life of hunting, balls, and entertainment. The most telling in that respect is a description of her ritual according to which on Sundays, after church service, Anna with her cortege went to her room "from the altar of the God of goodness and equality that proclaims all people to be brothers and prescribes to them mutual love and orders to the mighty benevolence for the weak"; in one room that she passed jesters had to wait for her in squatting position like hens laying eggs and they had to cackle, and courtiers amused themselves by drawing on their faces moustaches, etc.; in the cortege there were the relatives of Volkonskii, Golitsyn, and Apraksin and they had to watch this humiliation (383). The fact that this humiliating scene took place regularly after church service tells us a lot about the level of Anna's spiritual life as a Christian.

One letter to Saltykov provides another telling characteristic of Anna's character. Referring to Saltykov's report about burning of house of tsarevna Imeretinsk ${ }^{24}$ she pronounced a scornful rebuke: "you ascribe to her the title of highness (высочество) and in addition to it you call her monarch (государыня), but in our view this title should be given only to our name and for her it is enough that she is tsarevna from which it should be admitted the blunder of

\footnotetext{
21 Münnich, op. cit., p. 176. Anna inherited from her mother "superstitious devotion," according to Waliszewski, op. cit., p. 166. "She was pious and even somewhat superstitious" which was expressed in her beliefs in astrological predictions, Александр Вейдемейер, Обзор главнейших происшествий в России, Санктпетербург: В типографии департамента внешней торговли $1835^{3}$, vol. 2, pp. 162-163; (Т 8). It appears that this kind of superstition led to the ukase prohibiting to bring to Russia Polish calendars since two of them had some predictions about Ukraine with "maliciously invented and unseemly passages" that can deceive people (PSZ 10.7715). It was Rzymski y ruski kalendarz z prognostykiem of Stanisław Niewieski.

22 The number of churches in the $18^{\text {th }}$ century was between 17.2 and 18.4 thousand (T 237 note 1 ).

23 К 22; Переписка графа С.А. Салтыкова с архимандритом Варлаамом и императрицею Анною Ивановной. 1732-1735, Русский архив 1900, no. 8, p. 430.

24 Apparently, имеретинска царевна Дарья Арчиловна (1678-1740), princess Darya/Darejan of Imereti (in Georgia).
}

your secretaries that they write that way mindlessly and you, perhaps without noticing it, signed this report, but you should first watch them that they do not ascribe something to someone what does not belong [to them]" (K 168). Never mind that the tsarevna lost her house in fire. The only thing that Anna could say was that Saltykov referred to the tsarevna using an apparently wrong title. To this category belongs also her ukase concerning one Matveev who erased the imperial title from some document, for which he was flogged "[to instill] fear in others" (PSZ 11.8159).

Anna was devoted to her entertainment and everything else took the second place. In this entertainment she showed her boorish, even sadistic streak, lack of sensitivity to others, enjoying seeing pain and humiliation of people, and she showed her thin-skinned responses to real or imaginary infractions. As to her role as an empress-politician, it appears that she left making policies for the large part to others, particularly to the Cabinet. For the first two months (end of 1731) she participated in its sessions, but in 1732 , she participated only in two sessions. ${ }^{25}$ The business was run by the vice-chancellor Ostermann and the favorite Biron using sometimes the help of Prokopovich and Ushakov and possibly others. The Cabinet thus issued ukases even in the absence of Anna. ${ }^{26}$ When documents were presented to her, "she signed the papers most often without reading them" (D 378). In fact, from mid-1735, her ukases could be signed only by the three members of the Cabinet (9.6745). As to the church policies, Biron did not express any interest in them. ${ }^{27}$ In the first half of her reign, Prokopovich exercised considerable influence driven to a large extent with the desire to settle scores with his ecclesiastical enemies, in which he proved to be very skillful. Throughout her reign, as with other policies, church policies were largely determined by the Cabinet in which the interest of the government took priority over religious interests of the church. The church was considered as a very important resource (material goods, taxes) and as a spiritual resource by spiritually enforcing the cohesion of society and loyalty to the government considered to be divinely appointed. Anna sometimes had a hand in allocating some money to a particular church or monastery, but many times she expressed strong interest in punishing those ecclesiastics who, in her mind, undermined her autocracy. Large issues of church policies were not in her sphere of interest and comprehension. This does not mean that she was unaware of what policies were made, particularly when it concerned her. She treated not saying proper prayers in church services, worse yet, not taking the oath of loyalty as personal insult worthy of most severe punishment as an attack on her autocracy. And so, she did not have qualms when signing sentences against lay people and ecclesiastics. 20,000

\footnotetext{
25 Бумаги кабинета министров императрицы Анны Иоанновны, 1731-1740 гг., Сборник Императорскаго Русскаго историческаго общества 104 (1898), pp. xliii-xliv, 111, 291.

26 Waliszewski, op. cit., pp. 190-191.

27 Т 13. Игорь Курукин, Бирон, Москва: Молодая гвардия 2006, p. 285 .
} 
people were sent to Siberia. ${ }^{28}$ The French ambassador de la Chétardie spoke about 7,200 victims of Anna's government sentenced to death and 30,000 sent to Siberia, ${ }^{29}$

\footnotetext{
28 Веретьев, op. cit., p. 35.

29 Letter from Dec. 30 1740, Сборник Императорскаго Русскаго историческаго общества 92 (1894), p. 197. On wide array of offences punished by death (decapitation, hanging, impaling, quartering) see А[лександр] С. Парамонов, О законодательстве Анны Иоанновньл: опьт систематическаго изложения, Санкт-Петербург: Типография “Север” А.М. Лесмана 1904, pp. 140-142.
}

Prussian ambassador Mardefeld, only counted 5,002 death sentences and also 30,000 exiled to Siberia. ${ }^{30}$ Her policies did not improve the position of the church and the situation in the church. Because of needs of the war, the church was depleted of human and financial resources. On the whole, secularization of the church made a further step since Peter started it and it would take Catherine II to complete it.

30 Letter from Jan. 7, 1741, Архив Князя Воронцова 25 (1882), p. 95.

\section{Bibliography}

Barthold, F[riedrich] W., Anna Joanowna. Cabinet, Hof, Sitte und gesellschaftliche Bildung in Moskau und St. Petersburg, Historisches Taschenbuch 7 (1836), 175-396.

Crummey, Robert O., The Old Believers and the world of Antichrist; the Vyg community and the Russian State, 1694-1855, Madison: University of Wisconsin Press 1970.

Dashkova, Ekaterina R., Memoirs of the Princess Daschkaw, London: Henry Colburn 1840.

Dolgorukov, Petr V., Mémoires du Prince Pierre Dolgoroukow, Genève: Cherbuliez 1867, vol. 1.

Manstein, [Christopher Herman], Memoirs of Russia, London: Printed for T. Becket and P.A. De Hondt 1770.

Münnich, Ernst von, Die Memoiren, Stuttgart: Verlag der I.G. Cotta'schen Buchhandlung 1896.

Waliszewski, K[azimierz], L'héritage de Pierre le Grand, Paris: Librairie Plon 1900.

Бумаги кабинета министров императрицы Анны Иоанновны, 1731-1740 гг., Сборник Императорскаго Русскаго историческаго общества 104 (1898).

Вейдемейер, Александр, Обзор главнейших происшествий в России, Санктпетербург: В типографии департамента внешней торговли $1835^{3}$, vol. 2 .

Веретьев, Н. Ю., Анна Иоанновна, ее личность, интимная жизнь и правление, Berlin: Heinrich Caspari Verlagebuchhandlung 1912.

Крафт, Георг В., Подлинное и обстоятельное описание построеннаго в Санктпетербурге в генваре месяие 1749 года Ледянаго дома и всех находившихся в нем домовых вещей и уборов: С приложенныли при том гридорованными фигурами, Также и некоторыми примечаниями о бывшей в 1740 году во всей Эвропе жестокой стуже, [Санктпетербург]: Печатано при Императорской Академии наук 1741.

Крафт, Г[еорг] Ф., Ледяной дом, Русская Старина 7 (1873), no. $3,354-360$.

Кудрявцев, А. (ed.), Книга записная имянным письмам и указам Императриц Анны Иоанновны и Елисаветы Петров- ны Семену Андревичу Салтыкову. 1732-1742 гг., Чтения в Императорском обществе истории и древностей российских при московском университете 1878, bk. 1, 1-236.

Курукин, Игорь, Анна Иоанновна, Москва: Молодая гвардия 2014.

Курукин, Игорь, Бирон, Москва: Молодая гвардия 2006.

Парамонов, А[лександр] С., О законодательстве Анны Иоанновны: опыт систематическаго изложения, Санкт-Петербург: Типография “Север” А.М. Лесмана 1904.

Переписка графа С.А. Салтыкова с архимандритом Варлаамом и императрицею Анною Ивановной. 1732-1735, Русский архив 1900, по. 8, 417-441.

Письма русских государей и других особ ияарскаго семейства: [vol. 4:] Переписка гериогини Курляндской Анны Ивановны, Москва: В типографии Сергея Орлова 1862.

Полное собрание постановлений и распоряжений по ведомству Православнаго Исповедания Российской империи, Санкт-Петербург: Синодальная. типография 1869-1915.

Полное собрание законов Российской Империи, Санктпетербург: Печатано в Типографии II Отделения Собственной Его Императорскаго Величества Канцелярии 1830.

Смирнов, П[етр] С., Правовое положение раскола при императрице Анне Иоанновне, Христианское чтение 1906, no. 1 , pp. 112-128.

Строев, В[асилий Н.], Бироновщина и Кабинет министров. Очерк внутренней политики Императрицы Анны, vol. 1, Москва: Типография Императорскаго Московскаго Университета 1909, p. 27; Евгений А. Anisimov, Анна Иоанновна, Москва: Молодая гвардия 2002.

Титлинов, Б[орис] В., Правительство императрицьь Аннь Иоанновны в его отночениях $\kappa$ делам православной иеркви, Вильна: Типография “Русский почин” 1905.

Шубинской, С.Н.; Императрица Анна Иоанновна, придворный быт и забавы, 1730-1740, Русская Старина 7 (1873), no. 3, 336-351.

Нащокин, Василий А., Записки, Русский архив 1883, по. 4, 245-351. 


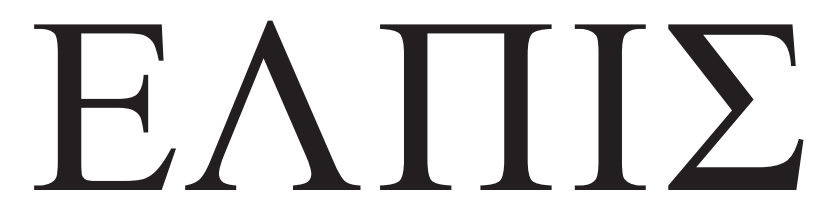

CZASOPISMO TEOLOGICZNE KATEDRY TEOLOGII PRAWOSŁAWNEJ UNIWERSYTETU W BIAŁYMSTOKU

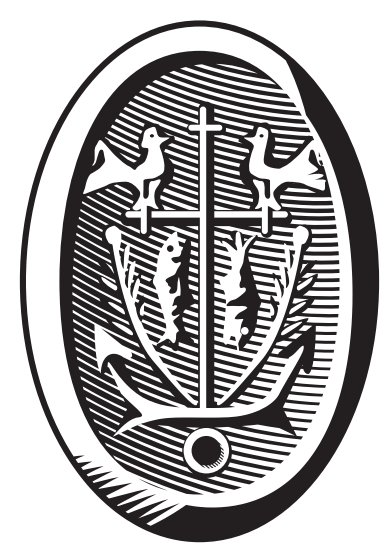

ADRES REDAKCJI

ul. Ludwika Zamenhofa 15, 15-435 Białystok, Polska tel. 85 745-77-80, e-mail: elpis@uwb.edu.pl www.elpis.uwb.edu.pl 